\title{
Bond between Steel Reinforcement Bars and Seawater Concrete
}

\author{
Adnan ${ }^{\mathrm{a}}$, Herman Parung ${ }^{\mathrm{b}}$, M. W. Tjaronge ${ }^{\mathrm{b}}$, Rudy Djamaluddin ${ }^{\mathrm{b}}$ \\ ${ }^{a}$ Ph.D. Student, Department of Civil Engineering, Hasanuddin University, Makassar and 90245, Indonesia. \\ ${ }^{b}$ Department of Civil Engineering, Hasanuddin University, Makassar and 90245, Indonesia.
}

Received 29 July 2020; Accepted 09 November 2020

\begin{abstract}
In order to promote sustainable development in the remote islands this present research attempted to study the suitability of seawater, that available abundantly surrounding the remote islands with Portland composite cement (PCC) and crushed river stones to produce concrete. This research aims to utilize seawater, and Portland composite cement (PCC) to produce high-performance concrete in order to eliminate the main problems of clean water shortage in the low land areas and the remote islands. Infrastructure development can be sustained through the effective use of natural available local materials on the remote islands. The method used in this research is an experimental method in the laboratory. Two variations of concrete were made using freshwater and seawater, respectively as a mixing material with a water to cement ratio $(\mathrm{w} / \mathrm{c})$ of 0.55 . The evaluation result on concrete compressive strength and bond strength of seawater concrete were discussed. Experimental results showed the compressive strength of the seawater concrete is lower by $6.26 \%$ as compared to the normal concrete at water-cement ratio (w/c) of 0.55 . In addition, the bonding strength of steel bar embedded in seawater concrete is lower by $4.34 \%$ as compared to the bonding strength of steel bar embedded in normal concrete at water-cement ratio (w/c) of 0.55 .
\end{abstract}

Keywords: Seawater Concrete; Normal Concrete; Portland Composite Cement; Compressive Strength; Bond Strength.

\section{Introduction}

Indonesia is an archipelagic country in the sense that at every location, there are buildings located on the coastal areas and remote islands. Hence the process of constructing buildings on the coastal areas and remote islands, have the high tendency to contact with seawater which is inevitable, coupled with the limited supply of freshwater to the construction site, therefore making use of seawater for concrete work is an interesting innovation. One important aspect of reinforced concrete is the compressive strength of concrete, the bonding strength of steel reinforcement to concrete, and the water cement ratio in concrete structures exposed in coastal areas.

Portland composite cement is one of the newest blended cement types that contain fly ash. Currently, Portland composite cement has been widely used in concrete construction in Indonesia. Several studies revealed that seawater and Portland composite cement can be used to produce high performance concrete [1-4].

A previous study on the bond strength of steel reinforcement to concrete with regard to cement water factors was conducted by Hwan and Kim (2007) [5], with purpose to propose a realistic model for bond tension-slip relationships. Another research based on bonding strength was conducted by Yalciner et al. (2012) [6], where the bond strength due to the un-corroded influence and the corrosive influence between reinforcement and concrete were studied in an experimental series. The purpose of the research conducted by Diab et al. (2014) [7] was to assess bond tension of the

* Corresponding author: adnanbojo.umpar@gmail.com

http://dx.doi.org/10.28991/cej-2020-SP(EMCE)-06

(C) 2020 by the authors. Licensee C.E.J, Tehran, Iran. This article is an open access article distributed under the terms and conditions of the Creative Commons Attribution (CC-BY) license (http://creativecommons.org/licenses/by/4.0/). 
low-strength concrete and high-strength concrete. Another research based on bonding strength conducted by Mostofinejad and Mohammadi (2020) [8] was the externally bonded reinforcement-strengthened specimens experienced a 3 and $9 \%$ decrease in their bond strength, and the externally bonded reinforcement on grooves-strengthened specimens experienced no decrease in bond strength and increases in the range of 7-19\%. Mousavi et al. (2020) [9] Indicate that as the crack width corresponding to the low confinement increases, rib sliding is expected to occur as an illustration of weak interfacial strength. McIsaac et al. (2019) [10] investigated the bond strength between concrete and fiber-reinforced polymer (FRP) wet lay-up systems using resins with biobased content of various proportions as a partial replacement of epoxy, which is well known to be an unsustainable product derived from petroleum. Moghaddas and Mostofinejad (2019) [11] Debonding failure is observed to occur in all of the specimens, the results obtained confirm the superiority of the externally bonded reinforcement on grooves over the externally bonded reinforcement specimens, as evidenced by an average enhancement of $31 \%$ achieved in bond strength and the postponed debonding. Experimental results in Mohammadi et al. (2017) [12] study showed that the specimens strengthened by the externally bonded reinforcement on grooves method and subjected to the adverse conditions of an alkaline environment resisted higher bond loads by up to $50 \%$ their ultimate bond loads compared to those strengthened via the externally bonded reinforcement method.Most of the previous studies mainly focus on the bond strength between reinforcement bar with normal concrete. Little studies have been conducted on comparing the seawater, and freshwater concretes, especially on microstructure analysis Mansyur and Permana (2020) [13]. The objective of this study was to reveal the compressive strength, elasticity, and microstructure of concrete using seawater and freshwater as the mixing water. However there are very limited information with regard to bond strength between reinforcement bars with seawater concrete. Based on aforementioned backgrounds, this research aimed to analyze the bonding strength of steel reinforcement bar embedded in the seawater concrete.

\section{Bonding Strength}

Bonding strength between reinforcement bar and concrete have been categorized in three classification according to ACI 408R-03 [14]: 1) the chemical adhesion between the reinforcement bar and surrounding concrete; 2) frictional forces caused by roughness between reinforcement bar and concrete; and 3) bearing forces on the concrete from the bar deformations. Bond strength is the ability of reinforcing steel and concrete covering it in resisting forces from the outside or other factors that can cause the detachment of bonding between reinforcing steel and concrete. Hence the bonding strength between reinforcing steel with concrete can be calculated by the Equation 1 [15].

$\tau_{\max }=\frac{P_{\max }}{\pi \cdot D \cdot l}$

Where:

$\tau_{\max }$ : Bond strength of reinforcement steel in concrete $\left(\mathrm{N} / \mathrm{mm}^{2}\right)$,

$\mathrm{P}_{\max }$ : Maximum load $(\mathrm{N})$,

D: Reinforcement steel diameter ( $\mathrm{mm})$,

$l$ : Embedded length (mm).

\section{Materials and Methods}

\subsection{Materials}

Concrete is generally composed of three main constituent materials, namely cement, aggregate, and water. In general, concrete contains about 1-2\% air content, cement paste (cement and water) around 25-40\%, and aggregates (fine aggregate and coarse aggregate) around $60-75 \%$, respectively. Table 1 shows the physical properties of PCC used to make normal concrete and sea water concrete in this study. The PCC used is a production from a national cement factory and available in the market. Tables 2 and 3 show the physical properties of coarse and fine aggregates respectively, that was used to make normal concrete and sea water concrete in this study. Coarse aggregate obtained from the crushed river stone and sand used as fine aggregate obtained from the Jeneberangriver, South Sulawesi Province. Sea water was collected from Barombong beach, South Sulawesi Province. Table 4 shows mix design of the concrete in $1 \mathrm{~m}^{3}$. Freshwater was used for making normal concrete and seawater was used to make sea water concrete. Normal concrete and seawater concrete were produced in the laboratory. After the fresh concrete is put into the compressive test mold and bonding strength test, the specimen is left for 24 hours in a room temperature of $27^{\circ} \mathrm{C}$ and a humodity of $65 \% \mathrm{RH}$. The test objects was then removed from the mold later. The test samples for compressive strength was cured in freshwater for normal concrete and seawater for seawater concrete.

Table 1. Physical properties of PCC cement

\begin{tabular}{ccccccc}
\hline \multirow{2}{*}{ Physical property } & \multirow{2}{*}{ Fineness } & \multicolumn{2}{c}{ Compressive strength $\left(\mathbf{N} / \mathbf{m m}^{2}\right)$} & \multirow{2}{*}{ Specific gravity } & Normal consistency (\%) \\
\cline { 3 - 5 } & & $\mathbf{3}$ days & $\mathbf{7}$ days & $\mathbf{2 8}$ days & & 25.15 \\
\hline Value & 382 & 18.86 & 26.81 & 41.79 & 3.03 & 25 \\
\hline
\end{tabular}


Table 2. Properties of coarse aggregate

\begin{tabular}{cc}
\hline Property & Value \\
\hline Maximum size & $19 \mathrm{~mm}$ \\
Water absorption & $2.10 \%$ \\
Bulk specific gravity & 2.63 \\
Saturated surface dry specific gravity & 2.68 \\
Apparent specific gravity & 2.78 \\
Flakiness index & $9.40 \%$ \\
Abrasion aggregate & $24.40 \%$ \\
\hline
\end{tabular}

Table 3. Properties of fine aggregate

\begin{tabular}{cc}
\hline Property & Value \\
\hline Water Absorption, & $2.79 \%$ \\
Bulk specific gravity & 2.45 \\
Saturated surface dry specific gravity & 2.52 \\
Apparent specific gravity & 2.63 \\
Sand Equivalent & $89.70 \%$ \\
\hline
\end{tabular}

Table 4. Mix design of normal concrete and seawater concrete $(w / c=0.55)$

\begin{tabular}{ccc}
\hline Material & Weight in $\mathbf{1} \mathbf{~ m}^{\mathbf{3}}$ concrete $\mathbf{( k g )}$ & Ratio to the amount of cement \\
\hline Water & 204.12 & 0.55 \\
Cement (PCC) & 371.13 & 1.00 \\
Sand & 590.39 & 1.59 \\
Coarse aggregate & 1099.29 & 2.96 \\
\hline
\end{tabular}

\subsection{Research Design}

Figure 1 shows the research design. This research uses freshwater and seawater as a mixing material of concrete with $\mathrm{w} / \mathrm{c}=0.55$. After the age of the specimen is 28 days, the compressive strength and pull out tests are carried out to determine the value of the bond strength value between freshwater concrete and seawater concrete.

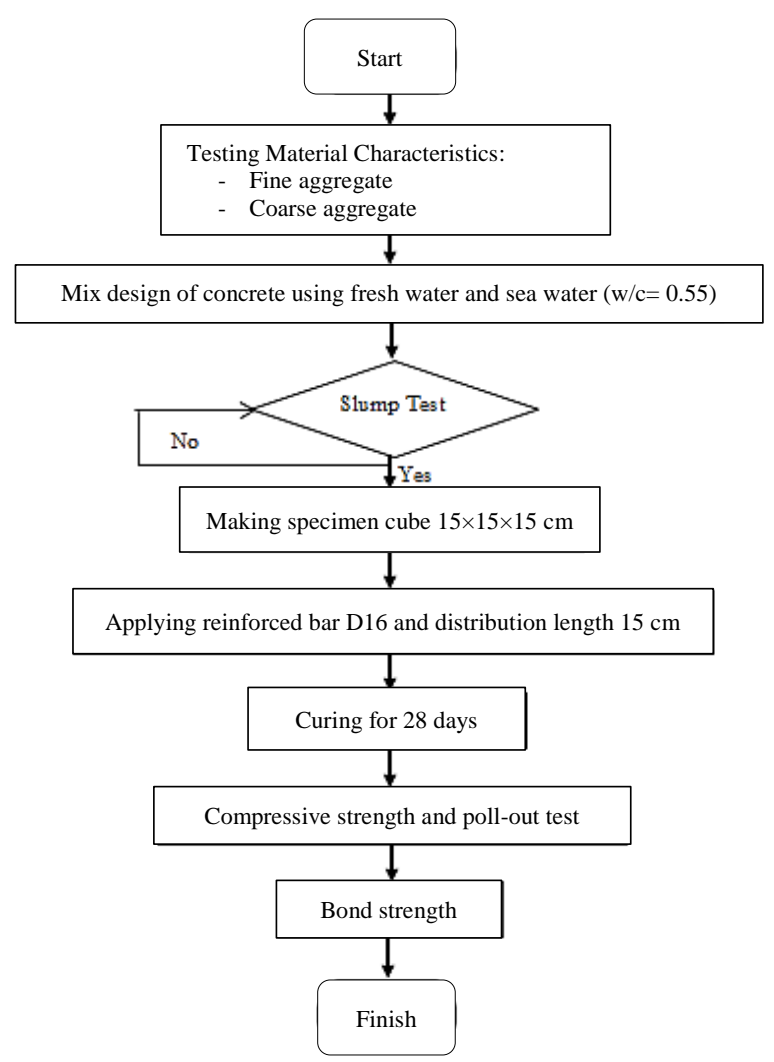

Figure 1. Flowchart of the research methodology 


\subsection{Pull-out Test}

In the test of bonding between concrete and reinforcement was carried out with reference to RILEM [16]. In this test, the specimen was placed on a flat plate of confinement cage and the reinforcement was subject to tensile loads. Such a method can cause compressive stress on the concrete on one side and tensile stress on the reinforcement on the other side. The selection of test specimens in this study was planned so that the stresses that occur can typify the stress conditions in reinforced concrete structures.

The pull out test set up to measure the bonding strength between the deformed steel bar and the concrete is shown in Figure 2. Based on the above considerations, this study determined a cube-shaped specimen with dimensions of $150 \times 150 \times 150 \mathrm{~mm}$ employed in the pull out test. Deformed steel bar with a diameter of $16 \mathrm{~mm}$ was embedded 5 times of its diameter (the bonded section length was $80 \mathrm{~mm}$ ). The pull-out load was gradually employed until attaining the ultimate bonding stress.

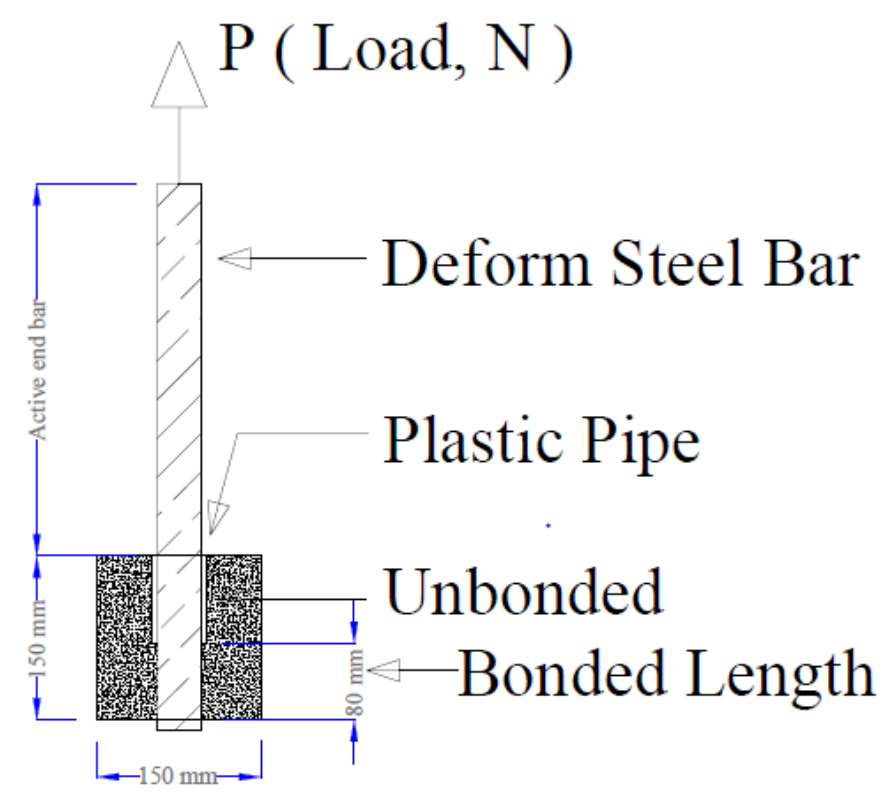

Figure 2. Set up of pull-out test

\subsection{Compressive Strength Test}

The compressive strength test is shown in Figure 3. The compressive strength test were carried out in three cubes specimens of dimensions $150 \times 150 \times 150 \mathrm{~mm}$. The specimens were tested with UTM machine at rate of compression loading of $0.3 \mathrm{~mm} / \mathrm{sec}$.

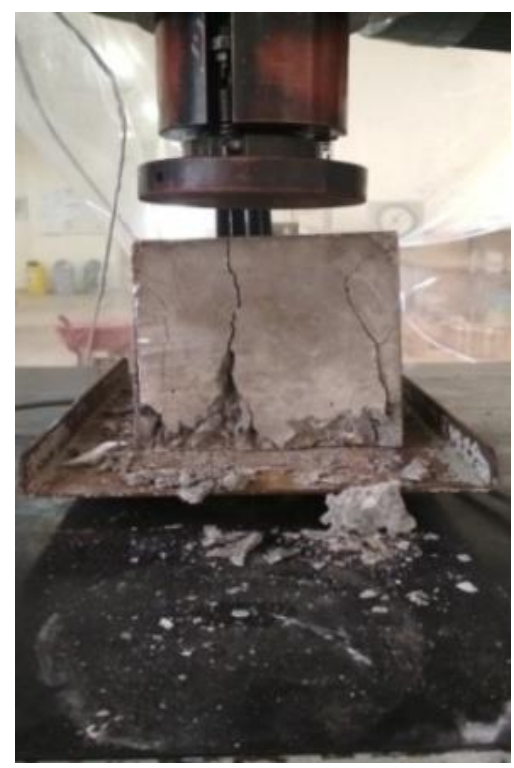

Figure 3. Compressive strength test (specimen cube $15 \times 15 \times 15 \mathrm{~cm}$ ) 


\section{Results and Discussion}

\subsection{Compressive Strength Test}

The results of the compressive strength test at 28 days are shown in Table 4 . At water-cement ratio (w/c) of 0.55 , the compressive strength of normal concrete is $23.00 \mathrm{~N} / \mathrm{mm}^{2}$, while seawater concrete has a compressive strength of 21.56 $\mathrm{N} / \mathrm{mm}^{2}$. These results indicate that the compressive strength of seawater concrete is $6.26 \%$ lower than that of normal concrete.

Table 5. The test results of the compressive strength

\begin{tabular}{|c|c|c|c|c|c|c|}
\hline No. & $\begin{array}{c}\text { Age } \\
\text { (days) }\end{array}$ & $\begin{array}{c}\text { Area } \\
\left(\mathbf{m m}^{2}\right)\end{array}$ & $\begin{array}{l}\text { Maximum } \\
\operatorname{load}(\mathbf{k N})\end{array}$ & $\begin{array}{c}\text { Compressive strength } \\
\left(\mathrm{N} / \mathrm{mm}^{2}\right)\end{array}$ & $\begin{array}{c}\text { Average } \\
\text { Compressive strength }\left(\mathrm{N} / \mathrm{mm}^{2}\right)\end{array}$ & Types of concrete \\
\hline 1 & \multirow{3}{*}{28} & \multirow{3}{*}{22500} & 537.21 & 23.88 & & \multirow{3}{*}{$\begin{array}{l}\text { Normal } \\
\text { w/c } 0.55\end{array}$} \\
\hline 2 & & & 511.61 & 22.74 & 23.00 & \\
\hline 3 & & & 503.69 & 22.39 & & \\
\hline 1 & \multirow{3}{*}{28} & \multirow{3}{*}{22500} & 495.81 & 22.04 & & \multirow{3}{*}{$\begin{array}{l}\text { Seawater } \\
\text { w/c } 0.55\end{array}$} \\
\hline 2 & & & 486.65 & 21.63 & 21.56 & \\
\hline 3 & & & 472.93 & 21.02 & & \\
\hline
\end{tabular}

\subsection{Bonding Strength}

In the pull-out test of steel reinforcement in normal concrete with a water cement ratio (w/c) of 0.55 , the test specimens were treated with water curing for 28 days without acceleration (normally there was no rust) as shown in Figure 4.

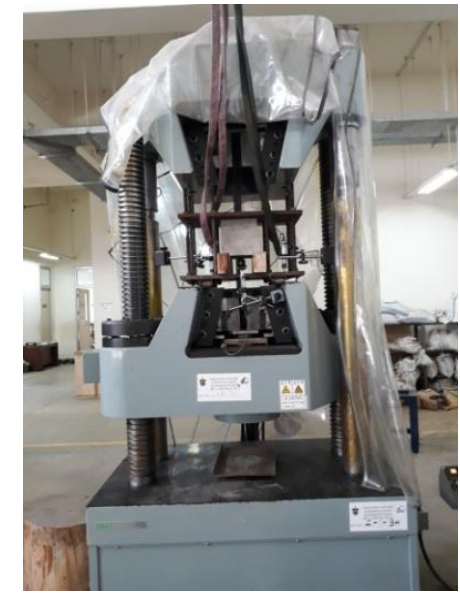

Figure 4. Pull-out test (specimen cube $15 \times 15 \times 15 \mathrm{~cm}$ )

Provide a grading curve for the used freshwater and seawater as a mixing materials of concrete with w/c $=0.55$ shows the research mix design (Figure 5).

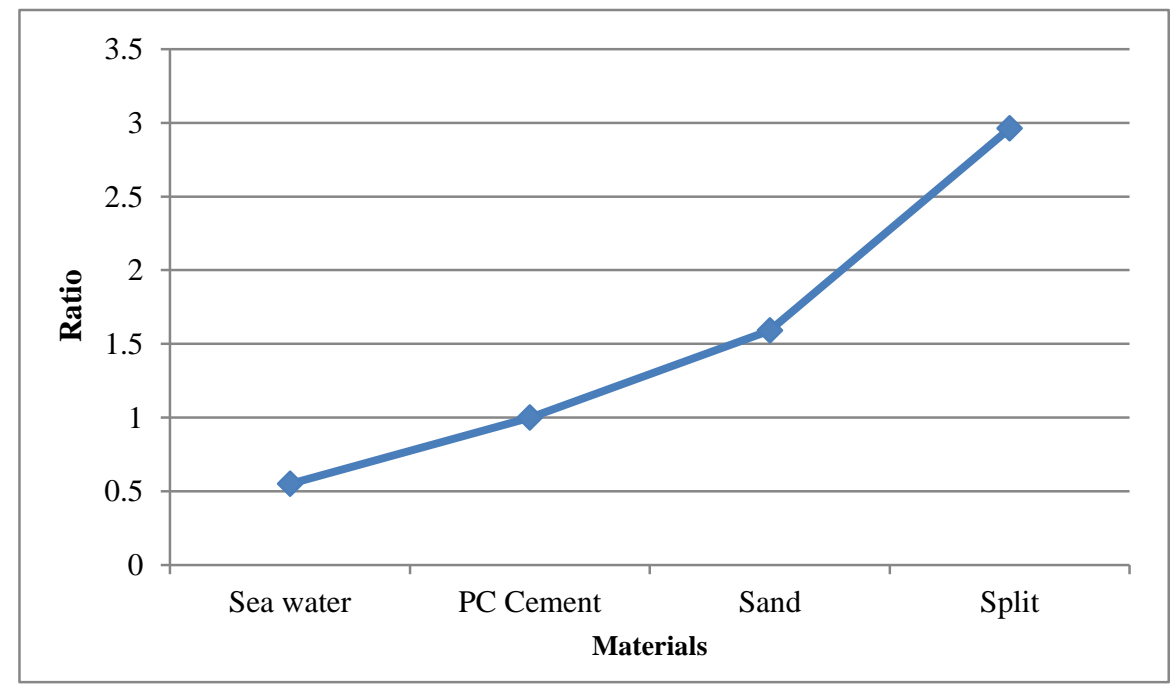

Figure 5. Curve for the used materials sea water concrete w/c 0.55 
Figures 6 and 7 are shown the relationship between tensile load and displacement.

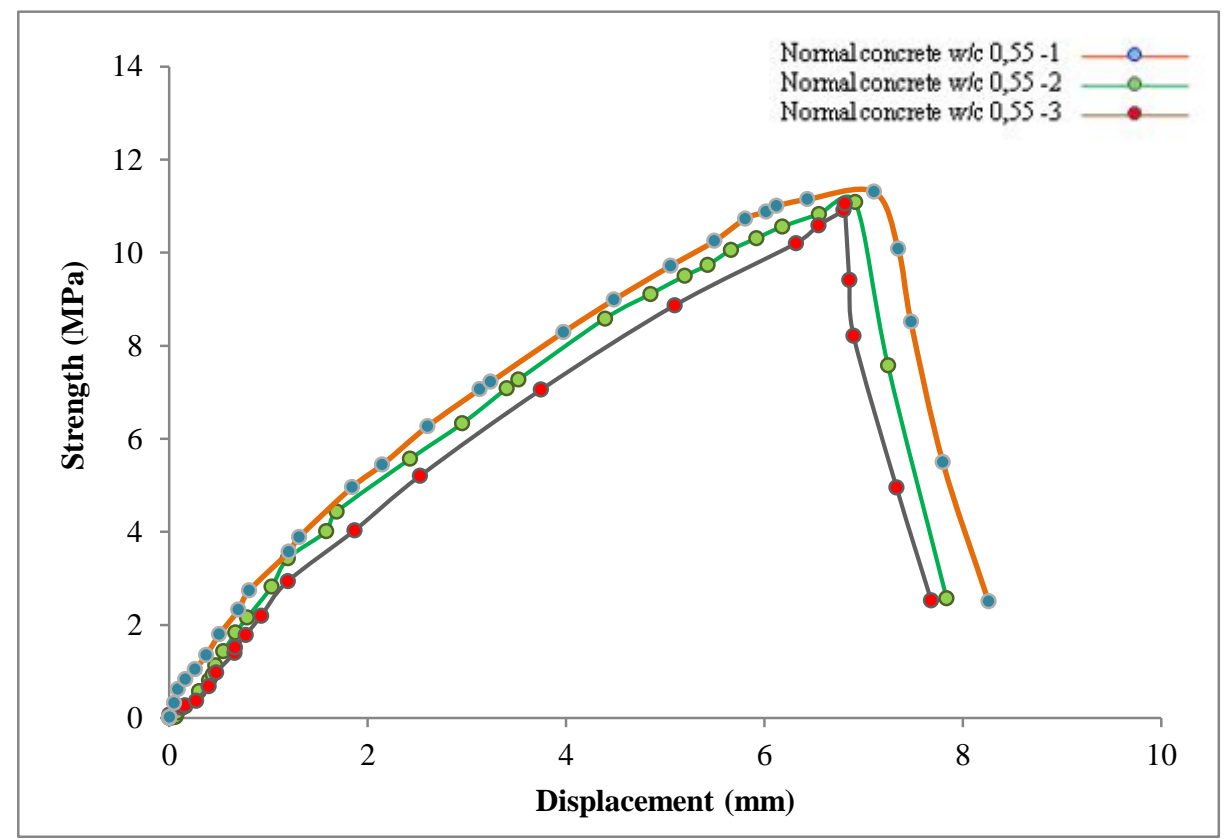

Figure 6. Relationship load to displacement w/c 0.55 (the sample normal concrete)

The maximum sample load for normal concrete specimens with a water cement ratio $(\mathrm{w} / \mathrm{c}=0.55)$ in Figure 6 , without acceleration (normal rust does not occur) on specimens 1, 2 and 3 are 44.548, 44.436 and $45.460 \mathrm{kN}$ respectively. The bonding strength values were 11.084, 11.056 and 11.311 MPa, respectively, with displacement of 6.916, 6.810 and 7.104 $\mathrm{mm}$, respectively.

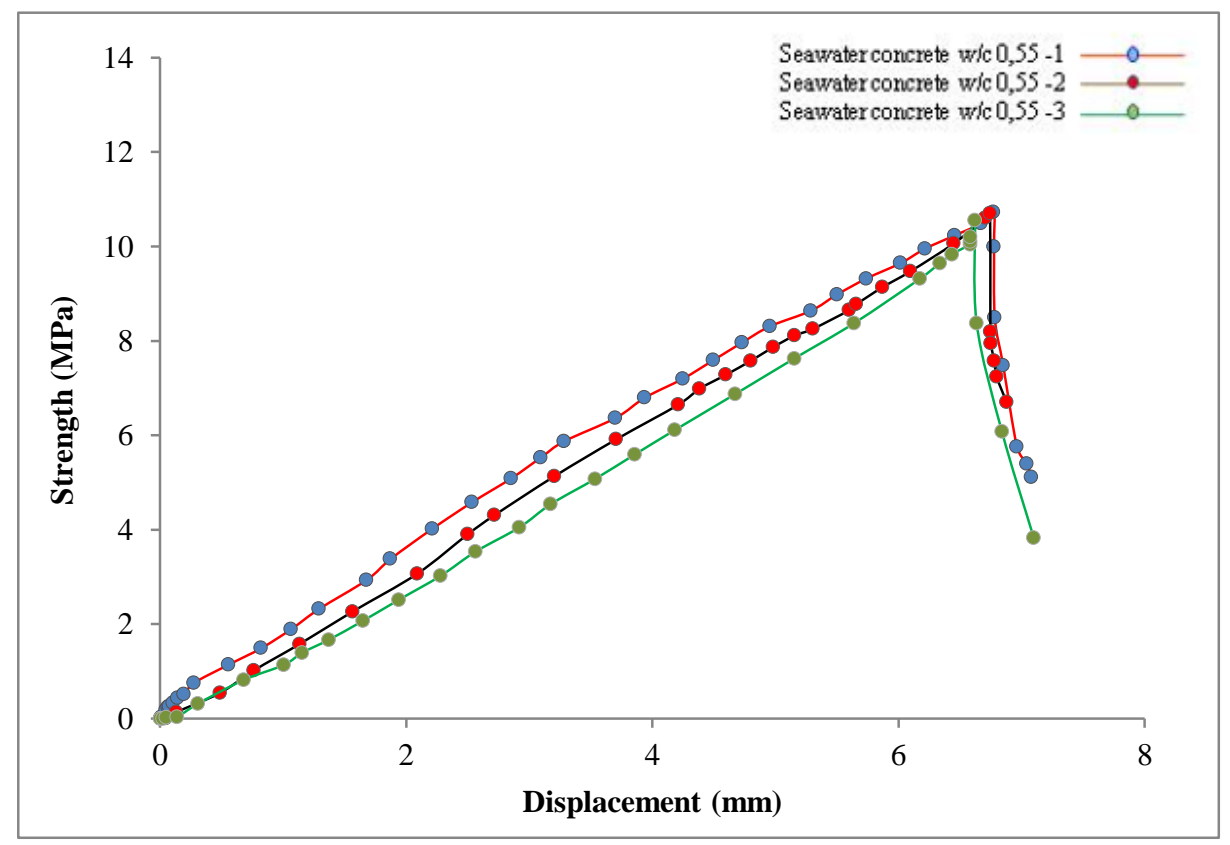

Figure 7. Relationship load to displacement w/c 0.55 (the sample sea water concrete)

The maximum sample load for sea water concrete specimens with a water cement ratio $(w / c=0.55)$ in Figure 7 , without acceleration (normally no rust occurs) on specimens 1, 2 and 3 are 43.128, 43.017 and $42.444 \mathrm{kN}$ respectively. The bonding strength values were $10.730,10.703$ and $10.560 \mathrm{MPa}$, respectively, with displacement of $6.772,6.744$ and $6.622 \mathrm{~mm}$, respectively.

Bonding strength of steel reinforcement embedded in concrete cube can be seen in Table 6. At water-cement ratio (w/c) of 0.55 , the bonding strength of normal concrete is $11.15 \mathrm{~N} / \mathrm{mm}^{2}$, while seawater concrete has a bonding strength of $10.66 \mathrm{~N} / \mathrm{mm}^{2}$. These results indicate that the bonding strength of seawater concrete is $4.34 \%$ lower than that of normal concrete. 
Table 6. Bonding strength and slip of steel reinforcement in concrete cube

\begin{tabular}{|c|c|c|c|c|c|c|}
\hline \multirow[t]{2}{*}{ No. } & \multirow{2}{*}{ Concrete } & $\begin{array}{l}\text { Reinforcement } \\
\text { diameter }(\mathbf{m m})\end{array}$ & $\begin{array}{l}\text { Embedded } \\
\text { length }(\mathbf{m m})\end{array}$ & $\begin{array}{l}\text { Load Max } \\
\quad(\mathbf{k N})\end{array}$ & $\begin{array}{c}\text { Bond strength } \\
\left(\mathbf{N} / \mathbf{m m}^{2}\right)\end{array}$ & \multirow{2}{*}{$\begin{array}{l}\text { Average Bond } \\
\text { strength }\left(\mathbf{N} / \mathbf{m m}^{2}\right)\end{array}$} \\
\hline & & D & $l$ & Pmax & $\tau_{\max }$ & \\
\hline 1 & \multirow{3}{*}{$\begin{array}{l}\text { Normal } \\
\text { concrete }\end{array}$} & \multirow{3}{*}{16} & \multirow{3}{*}{80} & 44.55 & 11.08 & \multirow{3}{*}{11.15} \\
\hline 2 & & & & 44.44 & 11.06 & \\
\hline 3 & & & & 45.46 & 11.31 & \\
\hline 1 & \multirow{3}{*}{$\begin{array}{l}\text { Sea water } \\
\text { concrete }\end{array}$} & \multirow{3}{*}{16} & \multirow{3}{*}{80} & 43.13 & 10.73 & \multirow{3}{*}{10.66} \\
\hline 2 & & & & 43.02 & 10.70 & \\
\hline 3 & & & & 42.44 & 10.56 & \\
\hline
\end{tabular}

\section{Conclusions}

The results of the experiments and analyzes carried out in this study can be concluded that the water cement ratio $(w / c)$ affects the compressive strength of concrete and the bonding strength of concrete. From the experiment, the compressive strength and bonding strength of sea water concrete to normal concrete with a water cement ratio is, the results of the analysis of the average compressive strength of sea water concrete with a water cement ratio w/c 0.55 of 21.561 MPa against normal concrete compressive strength of 23,000 MPa. The results of the analysis show a less pronounced decrease in compressive strength of 6.26\% against the compressive strength of normal concrete.

The result of the analysis of the average bonding strength of the test specimens sea water concrete with a water cement ratio of w/c 0.55 is $10.730 \mathrm{MPa}$ to normal concrete of $11.311 \mathrm{MPa}$. The results of the analysis of the bonding strength of sea water concrete showed a less pronounced decrease in bonding strength of 5.14\% w/c 0.55 to the bonding strength of normal concrete. Failure of the bond strength test specimen does not occur due to leaking of reinforcement and breaking of the concrete cover. The crack width of sea water concrete against normal concrete with a water cement ratio of $0.55 \mathrm{w} / \mathrm{c}$ seawater concrete is $0.15 \mathrm{~mm}$ against normal concrete is $0.10 \mathrm{~mm}$, the average difference is $0.05 \mathrm{~mm}$.

The results of the compressive strength analysis, the bonding strength of sea water concrete to normal concrete shows a subtle difference in the results of the analysis, so that the use of sea water together with Portland Composite Cement (PCC) as a material for concrete mixture is possible, especially for areas lacking clean water and isolated islands. The failure of the bond strength test object in the pull-out test did not occur in the form of cracking of the concrete cover and breaking of the reinforcement in the test object, to produce the expected pull-out test.

Based on this limited study of the bonding strength of steel bar in the normal concrete and the seawater concrete, the following findings were made:

- Normal and seawater concrete had compressive strength of 23.00 and $21.56 \mathrm{~N} / \mathrm{mm}^{2}$, respectively.

- Normal and seawater concrete had bonding strength of 11.15 and $10.66 \mathrm{~N} / \mathrm{mm}^{2}$, respectively.

\section{Funding and Acknowledgement}

This work was supported by the Indonesian Lecturer's Excellence Scholarship Program (BPPDN). Most of the research works were conducted in the Eco Material and Concrete Laboratory, Civil Engineering Department, Hasanuddin University, Makassar-Indonesia.

\section{Conflicts of Interest}

The authors declare no conflict of interest.

\section{References}

[1] Tjaronge, M. Wihardi, Rita Irmawaty, Sakti Adji Adisasmita, Arwin Amiruddin, and Hartini. "Compressive Strength and Hydration Process of Self Compacting Concrete (SCC) Mixed with Sea Water, Marine Sand and Portland Composite Cement." Advanced Materials Research 935 (May 2014): 242-246. doi:10.4028/www.scientific.net/amr.935.242.

[2] Raidyarto, A, H Parung, M W Tjaronge, and R Djamaluddin. "Flowability of Self-Compacting Concrete Containing Marine Materials and Steel Fiber." IOP Conference Series: Earth and Environmental Science 419 (February 8, 2020): 012055. doi:10.1088/1755-1315/419/1/012055.

[3] Erniati, M.W. Tjaronge, Victor Sampebulu, and Rudy Djamaluddin. "Porosity and Microstructure Phase of Self Compacting Concrete Using Sea Water as Mixing Water and Curing." Advanced Materials Research 1119 (July 2015): 647-651. doi:10.4028/www.scientific.net/amr.1119.647. 
[4] Adnan, H Parung, M W Tjaronge, and R Djamaluddin. "Compressive Strength of Marine Material Mixed Concrete.” IOP Conference Series: Materials Science and Engineering 271 (November 2017): 012066. doi:10.1088/1757-899x/271/1/012066.

[5] Oh, Byung Hwan, and Se Hoon Kim. "Realistic models for local bond stress-slip of reinforced concrete under repeated loading." Journal of Structural Engineering 133, no. 2 (2007): 216-224. doi:10.1061/(ASCE)0733-9445(2007)133:2(216).

[6] Yalciner, Hakan, Ozgur Eren, and Serhan Sensoy. "An Experimental Study on the Bond Strength between Reinforcement Bars and Concrete as a Function of Concrete Cover, Strength and Corrosion Level." Cement and Concrete Research 42, no. 5 (May 2012): 643-655. doi:10.1016/j.cemconres.2012.01.003.

[7] Diab, Ahmed M., Hafez E. Elyamany, Mostafa A. Hussein, and Hazem M. Al Ashy. "Bond Behavior and Assessment of Design Ultimate Bond Stress of Normal and High Strength Concrete.” Alexandria Engineering Journal 53, no. 2 (June 2014): 355-371. doi:10.1016/j.aej.2014.03.012.

[8] Mostofinejad, Davood, and Mahdie Mohammadi. "Effect of Freeze-Thaw Cycles on FRP-Concrete Bond Strength in EBR and EBROG Systems." Journal of Composites for Construction 24, no. 3 (June 2020): 04020009. doi:10.1061/(asce)cc.19435614.0001010.

[9] Mousavi, Seyed Sina, Lotfi Guizani, and Claudiane M. Ouellet-Plamondon. "Simplified Analytical Model for Interfacial Bond Strength of Deformed Steel Rebars Embedded in Pre-Cracked Concrete." Journal of Structural Engineering 146, no. 8 (August 2020): 04020142. doi:10.1061/(asce)st.1943-541x.0002687.

[10] McIsaac, Anne, Kenneth Mak, and Amir Fam. "Influence of Resin Biocontent and Type on Bond Strength Between FRP Wet Layup and Concrete.” Journal of Composites for Construction 23, no. 4 (August 2019): 04019029. doi:10.1061/(asce)cc.19435614.0000955 .

[11] Moghaddas, Amirreza, and Davood Mostofinejad. "Empirical FRP-Concrete Bond Strength Model for Externally Bonded Reinforcement on Grooves." Journal of Composites for Construction 23, no. 2 (April 2019): 04018080. doi:10.1061/(asce)cc.1943-5614.0000924.

[12] Mohammadi, Mahdie, Davood Mostofinejad, and Majid Barghian. "Effects of Surface Preparation Method on FRP-Concrete Bond Strength under Alkaline Conditions.” Journal of Composites for Construction 21, no. 4 (August 2017): 04017010. doi:10.1061/(asce)cc.1943-5614.0000786.

[13] Mansyur, Mansyur, and Dian Permana. "Mechanical Behaviour and Microstructure Characteristic of Concrete by Using Freshwater and Seawater.” Civil Engineering Journal 6, no. 6 (June 1, 2020): 1195-1203. doi:10.28991/cej-2020-03091540.

[14] ACI Committee, "Bond and Development of Straight Reinforcing Bars in Tension" (ACI 408R-03), American Concrete Institute, Farmington Hills, Mich., (2003): 48.

[15] Zhang, Xue, Wei Dong, Jian-jun Zheng, Zhi-min Wu, Yu Hu, and Qing-bin Li. "Bond Behavior of Plain Round Bars Embedded in Concrete Subjected to Lateral Tension." Construction and Building Materials 54 (March 2014): 17-26. doi:10.1016/j.conbuildmat.2013.12.031.

[16] Rilem/Ceb/Fip, Recommendation reinforcement steel for reinforced concrete. Revised edition of: RC 6 bond test for reinforcement steel; (2) Pull-out test, CEB News 73, Lausanne, Switzerland (1983). 